\title{
POSSIBILITIES OF INCLUDING DEVELOPERS INTO HOUSING STOCK REVITALIZATION
}

\author{
Sławomir Palicki, PhD \\ Department of Investment and Real Estate \\ Faculty of Management \\ Poznań University of Economics and Business \\ e-mail: Slawomir.Palicki@ue.poznan.pl \\ Lukasz Strączkowski, PhD \\ Department of Investment and Real Estate \\ Faculty of Management \\ Poznan University of Economics and Business \\ e-mail: Lukasz.Straczkowski@ue.poznan.pl
}

\begin{abstract}
The article aims at analyzing the possibility of including developers (private companies focused on profits) into the process of revitalizing tenement houses located in the center of Poznan. The consideration is located in the capital city of Wielkopolska and takes into account the analysis of both the local housing real estate market and developers' enterprises in the city. The authors, supported by economic calculation and a case study, have researched the case of a free-market developer's project of revitalizing a well-located, yet run-down tenement house, and, on the contrary, the case of a developer taking over a property being a municipal resource. Having researched the market in order to set the parameters of further research works, both scenarios where evaluated when it comes to their economic, social and spatial results.

The main purpose of the article was to analyze possibilities and to point out the determinant factors of using the economic potential of developers in the process of revitalizing housing resources located in downtown areas. The work is to contribute to the discussion on making the actions of public administration more flexible when it comes to cooperation with private investors. By outlining the research concept, the authors aim to set the basis for further and deeper analysis. The paper is to test the scientific community when it comes to the appropriateness of the diagnosis and the direction of potential research.
\end{abstract}

Key words: revitalization, housing, developer, tenement house, real estate, downtown.

JEL Classification: H79, L32, L38, L85, O18, R21, R23, R31, R38.

Citation: Palicki S., Strączkowski Ł., 2019, Possibilities of Including Developers into Housing Stock Revitalization, Real Estate Management and Valuation, vol. 27, no. 1, pp. 103-110.

DOI: 10.2478/remav-2019-0010

\section{Introduction}

Recently, there have been more and more opinions regarding the actual need of revitalizing downtown areas and including external entities, such as developers, in the process. Cities which are struggling with their revitalization processes point to the lack of financing the investment, the main source of money being the budget of the European Union. Run-down tenement houses are a big issue in downtown areas, and due to the fact that they are municipal properties, their decapitalization will be increasing. Such a phenomenon does not enhance the process of revitalization. 


\section{$\$$ sciendo}

Both the production capacity and experience of developers working on the real estate market of the biggest cities in Poland can be used in the processes of revitalizing downtown areas. It seems that the actions of public entities introducing revitalization procedures in accordance with the law are limited by their concern regarding the use of the municipal resource in an improper manner. In other words, there is doubt whether all the positive external effects created during revitalization processes will be used by the local society, rather than by business entities or real estate speculators. Such a fear might lead to local governments being too conservative when it comes to taking actions, and not taking full advantage of revitalization potential. The potential itself results from a proper and transparent dialogue with commercial entities such as developers.

The 2006 Polish bill on supporting revitalization, renovation and other construction investments (the project was ultimately rejected), expressed fear of "privatization" of revitalization effects (PROJEKT 2006). The suggested revitalization operator (the manager of the process), which would take responsibility for the program, could not be an entity running business activities unless it was an institution of public utility according to the regulations of the local government and municipal service. A given entity could not, in particular, be involved in any activities related to real estate, construction or the financial market. The need to protect the public interest and to ensure independence, honesty and selflessness of entities responsible for revitalization processes is of course understandable. Nevertheless, a controlled engagement of commercial entities such as developers, real estate agents, valuators, and property managers in cooperation with the managers of the process might support the action of public decision makers. The engagement could just take the form of a think-tank, or a platform to exchange thoughts and experiences which would support the process. Such a concept was not included in the project of the bill, as if it had been assumed that private entities focused on making profits would have had bad intentions. The multidimensional character of the revitalization is rejected here, as it is to affect social, public, cultural, economic, market and investment areas. The development in the revitalization process is to be comprehensive and long-lasting, which would lead to positive changes for the business community as well. It seems that instead of using the avoidance technique, the idea of considering honest and innovative ideas of commercial partners in revitalization processes is worth taking into account. By honest, the authors mean an action which would not allow external effects or undue public resources to be transferred to developers, but would allow them to make market profits at the same time. Such an attitude could be a fair and measurable incentive to take part in revitalization processes. An innovative and experimental model of cooperation between revitalization partners could become a win-win strategy in seemingly adverse circumstances.

\section{Literature review}

Revitalization is defined in literature in different ways (KACZMAREK 2001; PALICKI 2013; ROBERTS, SYKES 2002; ZIOBROWSKI 2000). According to the conclusions of the $1^{\text {st }}$ Congress for Revitalization of Polish cities, it is a "coordinated process of the local council, the local community and other participants, which is an element of developmental politics, run in order to prevent the degradation of urban spaces and crises, enhancing its development and quality changes by protecting the national heritage, while keeping to the rules of sustainable development" (ZIOBROWSKI 2010).

Between 1993-2013, the creative role of the local council connected with the spatial policy of a given area was underlined in several projects of the bill. It was suggested to join the revitalization program with the development plan of a district, its study of conditions and directions of spatial development, and with the local spatial management plan. The concept of balancing public and private interests, and of social participation were promoted as well. Social control was to become an obligatory element of introducing revitalization programs. The final definition, coming from the 2015 Bill of Revitalization Act, is: "Revitalization is a process of taking degraded areas out of crisis, by integrated actions in favor of the local community, area and economy, led in a complex manner by means of integrated actions taken by revitalization stakeholders based on the local revitalization program" (UsTAWA 2015).

An analysis of the potential effects generated in the revitalization process shows the particular importance of financial aspects of the process. The effectiveness of changes is questionable without proper capital being engaged in the process, both when it comes to economic and social postulates of revitalization. Changing the conditions of the process does lead to the differentiation of scenarios, but the accessibility of financial measures affects them the most (e.g. unequal treatment, economic strength/weakness when it comes to social negotiations, the accessibility of capital, 
increasing/decreasing potential profit, etc.). Such circumstances lead to including the real estate market in revitalization processes in cities (BILLERT 2015). The real estate market materializes real financial potential, gives area for speculation, and, by high purchasing costs, creates investment barriers (ADAIR et al. 2003). Due to its combination of features, it seems to be an important factor to the evolution of urban space in revitalization processes (BERNACIAK 2015; FAULK 2006). The real estate market generates, or, at least, conditions spatial competition (HERMANN 2016), and, as a result, is responsible, to a big extent, for creating a conflict of interest, which is a potential factor disturbing revitalization.

Due to its socio-economic importance, the real estate market in the housing area is subject to governmental intervention (MATUSIAK et al. 2017). Many attempts have been made to solve the socalled housing issue made in the last decades, such as social and tenement buildings or supporting both the purchase of flats and the rental market. State interventionism is also related to regulating the prices of flats and rents, blocking the construction of new buildings, and introducing construction tax incentives (KUCHARSKA-STASIAK 2016). The current housing market can be properly supported not only by the state and its interventionism, but also by several other factors, both external and internal. It is thought that the market is affected by endogenic factors, such as a stable and long-term housing policy of a country, the family policy, modern tools which make it possible to access market information easily or a well-functioning institution of the real estate market. The exogenic factors are the globalization process, innovations, and stable and predictable legal and tax regulations (FORYŚ 2011).

Including the real estate market and housing resources into revitalization processes has deep socioeconomic sense, especially in downtown areas (TANAŚ 2015), where the phenomenon of depopulation, caused by sub-urbanization, has been observed (STRACCZKOWSKI, SUSZYŃSKA 2012). Fulfilling social, civil and market tasks at the same time is possible at the housing market, which makes it an effective revitalization tool or even a ground for the process (ARBACI, RAE 2013; BEAUREGARD 2005; MORANDI 2011).

The local council of Poznan is aware of the need to coordinate the revitalization actions while creating its housing policy for 2017-2027. The new strategic document contains actions aimed at using the potential of developers in favor of housing development in revitalization programs (POLITYKA 2017):

- supporting revitalization processes in order to create friendly places to live, in particular by the means of a mechanism based on transferring the ownership of tenement houses to be revitalized to developers in exchange for them building blocks of flats, on the city's premises, for people who had previously been living in those tenement houses,

- exchanging the ownership of tenement houses or villas, which would be attractive for an investor when it comes to their location and architecture, to complete other tasks set by the city,

- having regular discussions with developers in order to exchange experiences between them and local officials,

- creating and using clear and transparent procedures when it comes to cooperation with investors. A very important role is to be played by the "developer's counselor",

- setting up cooperation with housing co-operatives and developers in order to build residential units and to make them available (e.g. the "flat for land" program).

An important novelty in the housing policy of Poznan is the multifaceted support of the diverse local society: numerous aims and tasks aimed at citizens requiring social help have appeared (housing policy as an element of the social policy), but the needs of wealthy people have been taken into consideration as well, by means of building premium houses - having high spatial quality and particular practical values (housing policy as an element of local development). The new housing policy shows the importance of undertaking actions which could reduce suburbanization and support the revitalization of downtown areas. The policy might also help to take advantage of the potential of properties in order to shape their surroundings (GAWRON 2000; KUCHARSKA-STASIAK 2016; WATT, SMETS 2017).

\section{Data and methods}

The following sources of information were used in order to elaborate on the possibility of engaging developers in revitalization processes: 


\section{$\$$ sciendo}

a) Own study, done at the Department of Investment and Real Estate at the Economic University in Poznan, concerning investors (developers) on the local market in Poznan. Based on chosen investments, it was possible to set an average price of $1 \mathrm{~m}^{2}$ and the time of selling flats. It has been established that the asking prices set by developers are acceptable on the market (small differences result from negotiations between parties), meaning they are not inflated.

b) A set of data regarding transactions at the local tenement house market. The set has been provided by the center of asset valuation (CWM Sp. z o.o.) in Poznan. On the basis of the aforementioned data it was possible to establish the price of $1 \mathrm{~m}^{2}$ to be paid by a developer undertaking the revitalization process of a tenement house.

c) A list of investments based on data made available by the Management of the Municipal Housing (ZKZL) in Poznan, regarding the costs of building $1 \mathrm{~m}^{2}$ of municipal housing area financed by Poznan. The average price of building $1 \mathrm{~m}^{2}$ has been established on the basis of this data.

d) Data from the National Bank of Poland regarding the price structure of $1 \mathrm{~m}^{2}$ of floor area in Poznan. The data made it possible to assess the potential profits and costs of a developer engaged in revitalization processes.

e) The announcement of the governor of Wielkopolska, dated 25th September 2017, regarding the conversion factor of the cost of recovering $1 \mathrm{~m}^{2}$ of usable area of a residential building in the Wielkopolskie voivodship. The piece of information shows the expenditure necessary to recover $1 \mathrm{~m}^{2}$ of a flat in Poznan between $1^{\text {st }}$ October 2017 and the 31 $1^{\text {st }}$ March 2018.

In order to present the issue, and the potential economic calculation of actions undertaken by developers, a simple comparison of the potential profitability of investment has been used. An astatic attitude towards the analysis has been taken, which should be sufficient to presenting the issue. When it comes to individual investments undertaken by single investors, it might be necessary to use dynamic methods of calculation such as NPV or IRR.

\section{Empirical results}

Taking into consideration information obtained from investors selling flats in the very city center of Poznan (between 2015-2017), it can be concluded that the possible yearly number of sold flats is approximately 120 (see Table 1.). There are investments with relatively higher and lower sales numbers as well. Particular investments differ when it comes to their pricing: the lowest average price of $1 \mathrm{~m}^{2}$ was 8100 PLN, whereas the highest was 11900 PLN. The average price of $1 \mathrm{~m}^{2}$ for all the investments was 9200 PLN.

Table 1

Investment and flats sale in the center of Poznan city in the years 2015-2017

\begin{tabular}{|c|c|c|c|c|}
\hline No. & Investor & Investment & $\begin{array}{l}\text { Average offer } \\
\text { price } 1 \mathrm{~m}^{2} \text { (in } \\
\text { thousand PLN) }\end{array}$ & $\begin{array}{c}\text { Average number } \\
\text { of flat sales per } \\
\text { year* }\end{array}$ \\
\hline 1 & Wechta & Orzeszkowej Str. & 8.6 & 2 \\
\hline 2 & REF Eastern Opportunities & Zajezdnia Poznań II & 8.1 & 60 \\
\hline 3 & Inwestycje Wielkopolski & 47 Półwiejska Str. & 9.2 & 21 \\
\hline 4 & NG Invest & Apartamenty Staromiejskie & 8.4 & 4 \\
\hline 5 & Jakśbud & 9 Dominikańska Str. & 11.9 & 10 \\
\hline 6 & Constructa Plus & Ogrodowa Str. & 9.7 & 0 \\
\hline 7 & Wechta & 8 Wenecjańska Str. & 8.6 & 6 \\
\hline \multirow[t]{2}{*}{8} & Konimpex Invest & 23 Mostowa Str. & 9.1 & 16 \\
\hline & & Total & $x$ & 119 \\
\hline
\end{tabular}

*Estimations based on developers information about the number of flats sold during the first quarter of the year.

Source: own calculations based on studies of KIiN UEP.

The next step taken in order to evaluate the cost of purchasing $1 \mathrm{~m}^{2}$ of housing area in a tenement house was the collation of sales transactions on the local market of tenement houses located in the center of Poznan. Having verified the data, and separated buildings which required additional renovation expenditure, it was possible to identify 25 such transactions between 2014-2016. 
Table 2

Transaction prices of tenement houses situated in the center of Poznan in the years 2014-2016

\begin{tabular}{rlrr}
\hline No. & & Measure & \multicolumn{2}{c}{$\begin{array}{c}\text { Area } \\
{\left[\mathrm{m}^{2}\right]}\end{array}$} & \multicolumn{1}{c}{$\begin{array}{c}\text { Price of } 1 \mathrm{~m}^{2} \\
{[\mathrm{z}]}\end{array}$} \\
\hline 1 & Average & 1030 & 2445 \\
\hline 2 & Minimum & 271 & 887 \\
\hline 3 & Maximum & 2532 & 4577 \\
\hline 4 & Median & 919 & 2172 \\
\hline
\end{tabular}

Source: own calculations based on data from CWM Sp. z o.o.

The analysis of the resources shows that the average area of a sold tenement house was $1030 \mathrm{~m}^{2}$, the smallest was $271 \mathrm{~m}^{2}$, and the biggest $2532 \mathrm{~m}^{2}$. If prices are to be taken into consideration, the average price of $1 \mathrm{~m}^{2}$ was 2445 PLN, the lowest 871 PLN, and the highest 4577 PLN (see Table 2). On this basis, it was assumed, for further elaboration, that the average price to be paid by an investor acting in the tenement house revitalization area is 2445 PLN.

Table 3

Costs of building $1 \mathrm{~m} 2$ of flat in municipal housing investments in Poznan

\begin{tabular}{clc}
\hline No. & \multicolumn{1}{c}{ Location } & $\begin{array}{c}\text { Costs of building } \\
\text { 1m2 [PLN] }\end{array}$ \\
\hline 1 & Dymka Str. & 2800 \\
\hline 2 & Bolka Str. - part 1 & 2200 \\
\hline 3 & Bolka Str. - part 2 & 2200 \\
\hline 4 & Zawady Str. & 2900 \\
\hline 5 & Biskupińska Str. & 2700 \\
\hline & & Average \\
\hline
\end{tabular}

Source: own calculations based on data from ZKZL Sp. z o.o.

The next step was establishing the costs of building $1 \mathrm{~m}^{2}$ of a new area in municipal housing. In order to do so, current housing investments made by the city were identified. It turned out that the costs of building $1 \mathrm{~m}^{2}$ are different. The lowest cost was established as 2200 PLN, and the highest 2900 PLN. The average value is 2560 PLN (see Table 3) - and such a value has been accepted for further analysis.

There are two additional pieces of information which have an important meaning - the cost of recovering $1 \mathrm{~m}^{2}$ of housing area in the Wielkopolska voivodship (it has been accepted that such information reflects the level of expenditure on $1 \mathrm{~m}^{2}$ of revitalized flats in Poznan), and the structure of the price of $1 \mathrm{~m}^{2}$ in Poznan, which helps to assess the profit of a potential investor engaged in revitalization processes, and other costs of the developer.

On the basis of the most recent governor's announcement (currently binding), dated 25 ${ }^{\text {th }}$ September 2017, the cost of revitalizing $1 \mathrm{~m}^{2}$ of a flat in a tenement house is 5200 PLN.

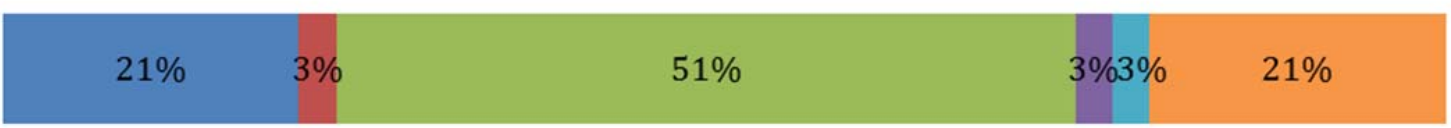

$$
\square \text { land } \square \text { project } \square \text { cost of building } \square \text { credit cost } \square \text { overhead costs } \square \text { developer's profit }
$$

Fig. 1. Structure of transaction price of $1 \mathrm{~m}^{2}$ of housing area. Source: own studies based on data of NBP. 
The data from NBP shows that the structure of the transaction price of $1 \mathrm{~m}^{2}$ comprises mostly of construction costs (51\%), and the land purchase costs (21\% of the entire price). Costs connected with design, credit and the, so-called, general costs are relatively low (see Fig. 1). From the point of view of research goals, it is important that the developer's profit is around $21 \%$ of the price. Thus, it could be assumed that the profit margin of a developer is approximately $20 \%$ of all costs.

The economic values obtained during the analysis were then used to create variants of proceedings in terms of revitalization and its potential effects - illustrated by Figure 2.
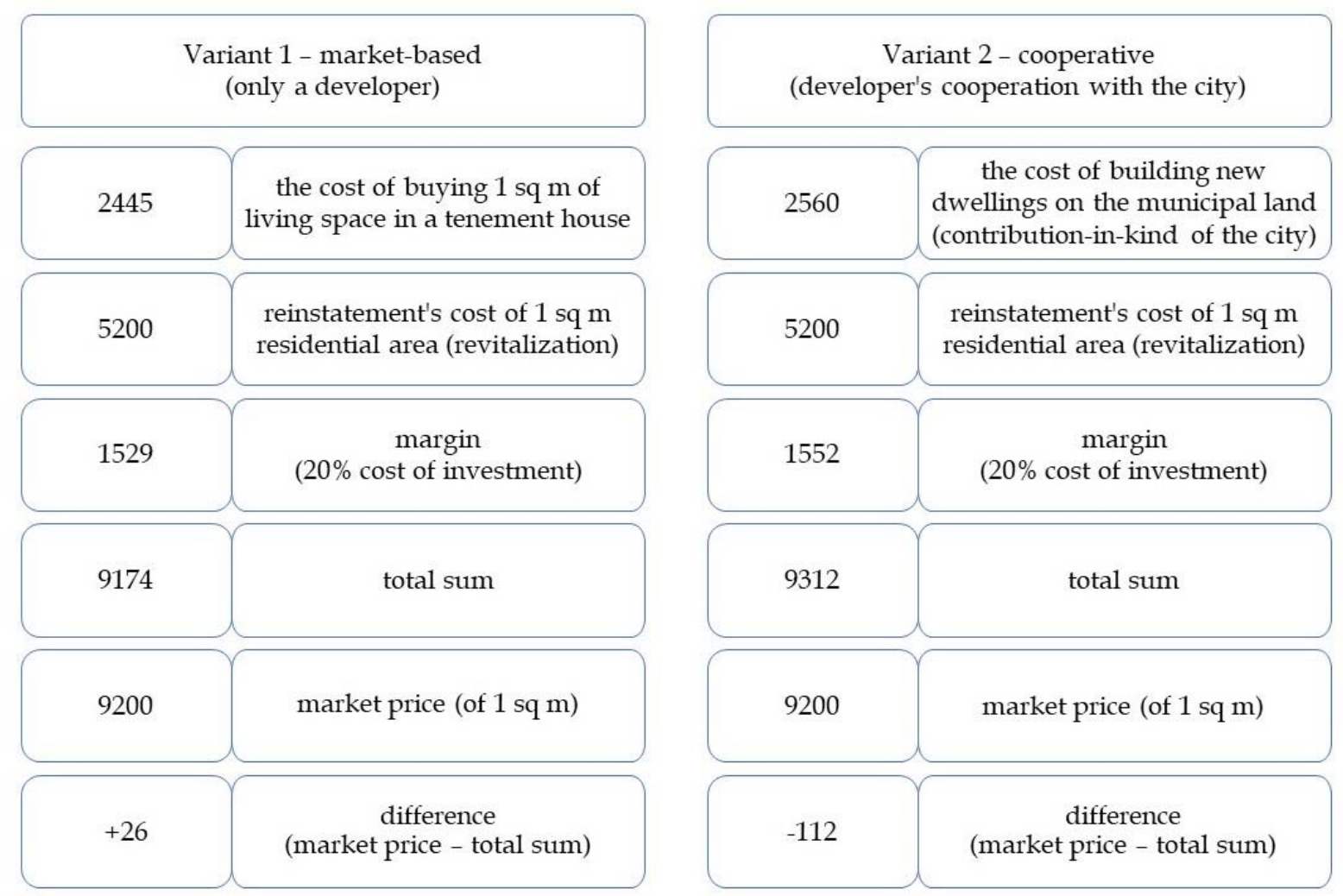

Fig. 2. The variants - the one of complete market freedom (the market-based or developers variant) and the cooperative one (the city-developer variant) in the process of tenement house revitalization in Poznan.

\section{Source: own studies.}

The first variant assumed the complete market freedom of a developer. This scenario, observed in practice, is a point of reference, and points to market conditions of revitalizing a tenement house. The developer single-handedly makes investments, earns the margin, and faces the risk of the investment.

In the second variant, the cooperative one, a very innovative cooperation between the city and the developer is created. The city transfers the ownership of a tenement house to the developer, but at the same time, appoints a plot of land (owned by the city), where the developer is obliged to build new municipal housing resources. Both parties have to face the risk of the investment, and its success depends on their proper cooperation and achieving complementary goals of both the city and the developer. The economic results in this variant are close to market values. Should any negative differences occur, a proper mechanism should be created (e.g. reducing the developer's margin, or the participation of the city in construction costs of municipal resources - depending on the agreement between the parties).

\section{Discussion and conclusions}

The suggested cooperation (city-developer) model might bring innovative effects in the area of revitalizing tenement houses in downtown areas. Undertaking such actions is obviously connected with discussion on the positive and negative outcomes on social, technical, spatial and market levels of local development. 
So-called good practices might be worked out thanks to cooperation between public and private entities. The practices might help to notice positive changes in the surroundings (discussed and desired), and, in the long-term perspective, to build new municipal resources, to improve the quality of public spaces and the models of public - private cooperation, and to take advantage of developers' know-how and experience. The investment and revitalization processes stay under public control but are performed by entities taking the market point of view into consideration.

There are, of course, particular negative sides of such an approach to the problem. Handing over public property to a private investor, for one, is highly debatable in Polish conditions. The issue of potential gentrification can be controversial as well. However, one has to take a look at the progressing degradation of downtown areas, which would generate more problems and high costs in the future. A degraded city center strengthens suburbanization process and decreases the level of an area's attractiveness to residents. The problem appears to have been noticed, as the last document on the housing policy of Poznan accepts the possibility of creating cooperation models between a public entity and a developer.

\section{References}

ADAIR A., BerRy J., MCGReAl S., 2003, Financing Property's Contribution to Revitalization, Urban Studies, 40(5-6), pp. 1065-1080.

ARbaCi S., RAE I., 2013, Mixed-Tenure Neighbourhoods in London: Policy Myth or Effective Device to Alleviate Deprivation? International Journal of Urban and Regional Research, 37(2), pp. 451-479.

BeAuREGARD R.A., 2005, The textures of Property Markets: Downtown Housing and Office Conversions in New York City, Urban Studies, 42(13), pp. 2431-2445.

BERNACIAK A., 2015, Wspótczesne przemiany centrów miast w świetle wybranych doświadczeń amerykańskich $i$ europejskich (Current Transformations of City Centres in Light of some American and European Experiences), Ruch Prawniczy, Ekonomiczny i Socjologiczny, 77(4), pp. 265-275.

BILlert A., 2015, Polityka rozwoju i rewitalizacja miast w Polsce, na tle standardów unijnych $w$ zakresie planowania (Policy of Development and Urban Renewal in Polish Cities against the Background of European Union Standards of Planning), http://www.urbanistyka.info/content/polityka-rozwoju-irewitalizacja-miast-w-polsce-na-tle-standard\% C3\% B3w-unijnych-w-zakresie-planow, 25.07.2015.

FaUlK D., 2006, The Process and Practice of Downtown Revitalization, Review of Policy Research, 23(2), pp. 625-645.

FORYŚ I., 2011, Społeczno-gospodarcze determinanty rozwoju rynku mieszkaniowego w Polsce (Socioeconomic Determinants of Development of Real Estate Market in Poland), Wydawnictwo Uniwersytetu Szczecińskiego, Szczecin.

GAWRON H., 2000, Znaczenie zarzadcy w gospodarowaniu nieruchomościami (Importance of Manager in Real Estate Management), Nieruchomości, Rynek i Prawo, 4 (23), pp. 23-27.

HERMANN B., 2016, Strategie na rynku kamienic wobec przemian funkcjonalnych w przestrzeni miejskiej (Strategies in the Market of Tenement Houses to Functional Changes in the Urban Space), Problemy Rynku Nieruchomości, 1(45), pp. 43-53.

KACZMAREK S., 2001, Rewitalizacja terenów poprzemystowych: nowy wymiar w rozwoju miast (PostIndustrial Areas Revitalization: a New Dimension in the Development of Cities), Wydawnictwo Uniwersytetu Łódzkiego, Łódź.

KUCHARSKA-STASIAK E., 2016, Ekonomiczny wymiar nieruchomości (The Economic Dimension of Real Estate), Wydawnictwo PWN, Warszawa.

MATUSIAK M., PALICKI S., STRĄCZKOWSKI Ł., 2017, Stan i kierunki rozwoju mieszkalnictwa w Metropolii Poznań (State and Directions of Housing Development in Poznań Metropolis), Bogucki Wydawnictwo Naukowe, Poznań.

MORANDI C., 2011, Retail and public policies supporting the attractiveness of Italian town centres: The case of the Milan central districts, Urban Design International, 16(3), pp. 227-237.

PALICKI S., 2013, Metody prospektywnej oceny nastęstw rewitalizacji obszarów miejskich (Methods of Prospective Evaluation of Urban Areas Revitalization After-Effects), Texter, Warszawa.

Polityka mieszkaniowa miasta Poznania na lata 2017-2027 (Housing Policy of Poznań City 2017-2027), 2017, Spółka Celowa Uniwersytetu Ekonomicznego w Poznaniu, Poznań. 
Projekt ustawy o rewitalizacji oraz wspieraniu remontów i niektórych inwestycji budowlanych (Project of the Act on Revitalization and Supporting Renovations and Certain Construction Investments), 2006, wWw.fr.org.pl, 25.11.2007.

ROBERTS P., SYKES H. (ED.), 2002, Urban regeneration: A handbook, SAGE Publications, London.

STRĄCZKOWSKI Ł., SUSZYŃSKA K., 2012, Housing Situation of Young Couples in the Light of the Local Housing Market Research, Actual Problems of Economics, 7(2), pp. 209-220.

TANAŚ J., 2015, Użytkowanie nieruchomości lokalowych w strefie centralnej Poznania (The Use of Real Estate Premises in the Central Area of the City of Poznań), Ruch Prawniczy, Ekonomiczny i Socjologiczny, 77(1), pp. 369-384.

Ustawa z dnia 9 października 2015 r. o rewitalizacji (The 9th of October 2015 Revitalization Act), 2015, http:/ / www.dziennikustaw.gov.pl/du/2015/1777/1, 21.02.2017.

WATT P., SMets P. (ED.), 2017, Social Housing and Urban Renewal: A Cross-National Perspective, Emerald Publishing, UK.

ZIOBROWSKI Z., 2000, Odnowa miast: Rewitalizacja, rehabilitacja, restrukturyzacja (Renewal of Cities: Revitalization, Rehabilitation, Restructuring), Instytut Gospodarki Przestrzennej i Komunalnej, Kraków

ZIOBROWSKI Z., 2010, Rewitalizacja miast polskich - podsumowanie projektu (Revitalization of Polish Cities Summary of the Project), Kraków, http:/ / www.sgh.waw.pl/katedry/kin/wydarzenia/poznan/ projekt_irm.pdf, 15.09.2012 